\title{
Forord
}

\section{NATURLIGE GODER? Forarbejdning af råvarer $i$ globale tider}

$\mathrm{D}$ ette temanummer af Tidsskriftet Kulturstudier er rundet af et kollektivt forskningsprojekt om naturressourcer ved navn Natural Goods? Processing Raw Materials in Global Times, som hører hjemme ved Saxo-Instituttet, Københavns Universitet. En grundlæggende præmis for projektet er, at det involverer en form for forarbejdning overhovedet at betegne noget som natur. Det betyder, at naturen ikke er derude som noget allerede givet, som vi kan bevæge os ind i og ud af eller lokalisere på afstand. Et perspektiv i forskningsprojektet er altså, at praksisser for fx observation, plukning, høst, indsamling og udvinding medproducerer det objekt, der overhovedet benævnes og kommer til syne som natur.

Dette indebærer, at det kræver en særlig indsats at skabe råvarer og få dem til at træde frem på en bestemt måde, som noget vi fx kan handle med, sætte pris på, kvantificere, klassificere, huske tilbage på, transportere, spise, regulere eller andet. Gennem tætte etnografiske, kulturanalytiske og kulturhistoriske udforskninger af, hvordan allehånde forarbejdningsprocesser materialiserer natur som naturressource, stiller temanummerets artikler skarpt på en serie specifikke praksisser og analyser, der genererer råvarer som te, kakao, frugter, guld, fisk, olie, lammekød og naturhistoriske samlinger.

Ved således at udforske naturressourcer som på én gang naturlige og forarbejdede, fundne og skabte, empiriske og analytiske peger vi på, at (kultur-) videnskabernes genstand aldrig udgøres af ubehandlede eller rå data, men altid også skabes af særlige interesser og perspektiver - i felten og i forskningen. Dette viser forskningsprojektets helt overordnede anliggende, nemlig en ambition om at anskue selve genereringen af empirisk materiale som en kreativ proces. Og hvorfor skulle naturen gå ram forbi en sådan ambition om generativ analyse?

Temanummerets samlede mål er at udfolde en sådan tilgang til råvarer, der ser dem som genererede af bestemte forarbejdningspraksisser. Fire af artiklerne er forfattet af forskningsprojektets deltagere, fire artikler af andre kulturforskere, 
men en styrende grundtanke, som alle bidragene kan læses i lyset af, er, at naturressourcer ikke er selvberoende og givne enheder, men derimod både genstande og motorer for uafsluttelige og indviklede historier. Som den franske sociolog Bruno Latour har formuleret det: „In spite of its reputation for indisputability, 'Nature' is the most complex entity there is and the hardest to invoke to bring a story to an end“ (Bruno Latour, Gifford Lectures 2013, s. 13).

Se mere på www.naturalgoods.saxo.ku.dk

God læselyst,

Redaktionen 